\title{
The Stability of Mycoplasma mycoides
}

\author{
BY A. W. RODWELL \\ Division of Animal Health, Animal Health Research Laboratory \\ C.S.I.R.O., Parkville, N. 2, Victoria, Australia
}

(Received 24, February 1965)

\section{SUMMARY}

The morphology of Mycoplasma mycoides was well preserved after washing and suspension in buffered 0.4 M-sucrose solutions, but the survival of viable particles was no better, and the loss of ultraviolet (u.v.)absorbing substances and the decrease of turbidity was no less than in hypotonic solution (0.01 M-tris $\mathrm{HCl}$ or $\left.0.01 \mathrm{M}-\mathrm{Na}_{2} \mathrm{HPO}+\mathrm{KH}_{4} \mathrm{PO}_{4}\right)$. The addition of $\mathrm{Mg}^{2+}, \mathrm{Ca}^{2+}$, spermidine or spermine (increasing order of activity) decreased the decrease of turbidity and loss of u.v-absorbing substances. $\mathrm{Ca}^{2+}$ and $\mathrm{Mg}^{2+}$, but not spermine, increased the degree of survival of viable particles. Ethylenediaminetetra-acetate (EDTA; 0.01 M) increased the loss of u.v.-absorbing substances, and decreased the turbidity and degree of survival. $\mathrm{Ca}^{2+}, \mathrm{Mg}^{2+}$ and spermine annulled the effects of EDTA on loss of u.v.-absorbing material and on the turbidity, but only $\mathrm{Ca}^{2+}$ prevented the lethal effect of EDTA. Filaments disappeared and cell volume increased when the organisms were transferred from hypertonic to hypotonic solutions; the shape changes were reversible.

\section{INTRODUCTION}

Smith \& Sasaki (1958) showed that the viability of some Mycoplasma strains was much less affected by the osmotic pressure of the suspending medium than had been supposed. Butler \& Knight (1960) confirmed this observation and showed also that metal-chelating agents (diethyldithiocarbamate, ethylenediaminetetra-acetate, 8hydroxyquinoline), manganese dioxide and the use of de-ionized water of high quality increased the degree of survival in suspensions in dilute buffer solutions. In contrast, $\mathrm{Ca}^{2+}$ ions have a marked stabilizing effect on bacterial spheroplast suspensions in hypotonic solutions (Tabor, 1962) and spermine, spermidine, streptomycin and polylysine were very effective stabilizers, while monovalent cations, $\mathbf{M g}^{2+}$ and the diamines 1,4-diaminobutane and 1,5-diaminopentane were relatively ineffective.

Razin \& Argaman (1963) compared the susceptibility of mycoplasmas, bacterial L-forms, spheroplasts and protoplasts to lysis by osmotic shock, by alternate freezing and thawing and by surface-active compounds. The mycoplasmas and bacterial L-forms were more resistant to osmotic shock than were the bacterial protoplasts and spheroplasts but, like the protoplasts, the mycoplasmas were very sensitive to lysis by surface-active substances. Mycoplasma strains differed in their sensitivity to lysis by osmotic pressure changes, strains of Mycoplasma mycoides being among the more resistant ones (Razin, 1963). Razin (1964) showed that the Mycoplasma strains he examined resisted osmotic shock at $0^{\circ}$, but underwent rapid lysis at $37^{\circ}$. Divalent and polyvalent cations, in concentrations as low as $10^{-5} \mathrm{M}$, protected Mycoplasma laidlawii from osmotic lysis. 


\section{METHODS}

Organisms. The strain $\mathrm{v} 5$ of Mycoplasma mycoides and the strain $\mathrm{N}$ of $\boldsymbol{M}$. capri were used. The latter strain has been found not to form detectable amounts of polysaccharide (Plackett, Buttery \& Cottew, 1963). The organisms were grown in supplemented BVF-OS medium (Plackett et al. 1963) and harvested when the turbidity of the cultures had increased to between one quarter and three quarters of the maximum expected value. Within this turbidity range, the organisms were highly filamentous and the ratio of colony count of viable particles to turbidity was approximately constant.

Reagents. The salts used were of AR quality; the water was glass distilled, but no special precautions were taken to prevent metal ion contamination. Spermine (grade B) and spermidine (grade A) were obtained from the California Foundation for Biochemical Research, and 1,4-diaminobutane from E. Light and Co. (Colnbrook, Bucks., England). Sucrose (M solution) was freed from cations by passage through Dowex $50\left(\mathrm{H}^{+}\right)$column. The solutions containing ethylenediaminetetraacetate and divalent metal ions were adjusted to $\mathrm{pH} 7 \cdot 4$ with $\mathrm{NaOH}$.

Procedure. Ten-ml. volumes of culture were chilled, and centrifuged at 15,000 rev./min. for $20 \mathrm{~min}$. (Spinco, model L, rotor 40). The supernatant fluids were poured off and the walls of the tubes wiped dry with filter paper. The deposits of organisms were then washed twice by resuspension in 10-ml. volumes of the test solutions. The entire process, which occupied about $3.5 \mathrm{hr}$, was performed in the cold.

Counts of viable particles determinations were made by a plate colony count method after the suspensions had been kept about $1 \mathrm{hr}$ at $0-2^{\circ}$, and again in most experiments after a further period of 1-3 days at $2^{\circ}$. The results are expressed as the $\%$ of the colony count of the original culture. Turbidity measurements were made at $650 \mathrm{~m} \mu$ (Beckman Model DU, $1 \mathrm{~cm}$. light path) on samples of the suspensions (warmed to room temperature) at the end of the storage period, and are expressed as $\%$ of the turbidity of the original culture. Leakage of u.v.-absorbing material was measured at $250 \mathrm{~m} \mu$ in both of the supernatant fluids after washing, and also in the supernatant fluid obtained after centrifuging a sample of the suspension after storage. The sum of these measurements, corrected where necessary for the extinction of the washing fluid, are expressed as \% of the extinction of an alkali lysate. For this, the unwashed pellet from $10 \mathrm{ml}$. culture was incubated at $37^{\circ}$ with $1 \mathrm{ml}$. $\mathrm{N}-\mathrm{NaOH}$ for $1 \mathrm{hr}$ and the lysate diluted to $50 \mathrm{ml}$. for measurement.

The volumes of packed cell pellets were measured after centrifugation in graduated capillary-tipped tubes at $1850 \mathrm{~g}$ for $18 \mathrm{hr}$ at $2^{\circ}$. Polyvinylpyrrolidone $(1 \%, \mathrm{w} / \mathrm{v}$, in the suspending fluid) was used as an indicator for measuring the intercellular volume (Wetherell \& Pollack, 1962).

Electron microscopy. Nine volumes of a solution of the same composition as that of the suspending fluid but containing in addition either $4 \%(w / v)$ formaldehyde or $5 \%(w / v)$ glutaraldehyde were added to 1 vol. of suspension of organisms. Phosphate buffer was used in the suspending fluid to avoid $\mathrm{pH}$ changes. After standing overnight at $2^{\circ}$, the organisms were washed and suspended in water. Droplets were air-dried on electron microscope grids before metal-shadowing. No differences in morphology between material fixed in formaldehyde or glutaraldehyde were 
detected, but the impression was formed from dark field examination in a light microscope that both fixatives resulted in some shrinkage, and in an increase in the number of beaded filaments.

\section{RESULTS}

Effects on turbidity, loss of ultraviolet-absorbing material and survival

$\mathrm{Mg}^{2+}, \mathrm{Ca}^{2+}$ and $\mathrm{EDT} \boldsymbol{A}$. There was a decrease in turbidity, a loss of u.v.-absorbing material from the organisms and a decrease in the colony count after washing the organisms in dilute tris or phosphate buffers $(0.01 \mathrm{M}, \mathrm{pH} 7 \cdot 4)$. The magnitude of

Table 1. The effect of $\mathrm{Mg}^{2+}$ and $\mathrm{Ca}^{2+}$ on the stability of Mycoplasma mycoides

\begin{tabular}{|c|c|c|c|c|c|}
\hline \multirow[b]{2}{*}{ Expt. } & \multirow{2}{*}{$\begin{array}{l}\text { Divalent cation salts* } \\
\quad \text { (M concn.) }\end{array}$} & \multirow{2}{*}{$\begin{array}{c}\text { Turbidity } \\
(\%) \dagger\end{array}$} & \multirow{2}{*}{$\begin{array}{l}\text { Extinction } \\
\text { at } 260 \mathrm{~m} \mu \\
(\%) \ddagger\end{array}$} & \multicolumn{2}{|c|}{$\begin{array}{l}\text { Viable count (\%) after } \\
\text { stated period at } 0-2^{\circ}\end{array}$} \\
\hline & & & & $\mathbf{l} \mathbf{~ h r}$ & $70 \mathrm{hr}$ \\
\hline 1 & $\begin{array}{l}\text { None } \\
\text { MgSO }_{4}(0 \cdot 001) \\
\mathrm{MgSO}_{4}(0 \cdot 01) \\
\mathrm{MgSO}_{4}(0 \cdot 1)\end{array}$ & $\begin{array}{l}50 \\
78 \\
84 \\
95\end{array}$ & $\begin{array}{l}44 \\
28 \\
24 \\
25\end{array}$ & $\begin{array}{l}13 \\
15 \\
60 \\
57\end{array}$ & $\begin{array}{l}0 \cdot 3 \\
0 \cdot 2 \\
21 \\
41\end{array}$ \\
\hline 2 & $\begin{array}{l}\text { None } \\
\mathrm{CaCl}_{2}(0 \cdot 001) \\
\mathrm{CaCl}_{2}(0 \cdot 01) \\
\mathrm{CaCl}_{2}(0 \cdot 1)\end{array}$ & $\begin{array}{l}60 \\
70 \\
87 \\
88\end{array}$ & $\begin{array}{l}35 \\
27 \\
20 \\
23\end{array}$ & $\begin{array}{l}49 \\
57 \\
44 \\
45\end{array}$ & $\begin{array}{l}8 \\
2 \cdot 5 \\
27 \\
19\end{array}$ \\
\hline
\end{tabular}

* Salts added to $0.01 \mathrm{M}$-tris $\mathrm{HCl}(\mathrm{pH} \mathrm{7.4)}$. † Percentage of culture. ‡ Sum of $260 \mathrm{~m} \mu$ extinction of washings as $\%$ of alkali lysate.

Table 2. The effect of $\mathrm{Mg}^{2+}$ and $\mathrm{Ca}^{2+}$ and $\mathrm{EDT} \mathrm{A}$ on the stability of Mycoplasma mycoides

\begin{tabular}{|c|c|c|c|c|c|}
\hline \multirow[b]{2}{*}{ Expt. } & \multirow{2}{*}{$\begin{array}{l}\text { Additions* } \\
\text { (M conen.) }\end{array}$} & \multirow{2}{*}{$\begin{array}{c}\text { Turbidity } \\
(\%) \dagger\end{array}$} & \multirow{2}{*}{$\begin{array}{l}\text { Extinction } \\
\text { at } 260 \mathrm{~m} \mu \\
(\%) \ddagger\end{array}$} & \multicolumn{2}{|c|}{$\begin{array}{l}\text { Viable count (\%) after } \\
\text { stated period at } 0-2^{\circ}\end{array}$} \\
\hline & & & & $1 \mathrm{hr}$ & $70 \mathrm{hr}$ \\
\hline 1 & $\begin{array}{l}\text { None } \\
\text { EDTA (0.001) } \\
\text { EDTA (0.01) } \\
\text { MgSO }_{4}(0.01) \\
\text { EDTA }(0.001) ; \mathrm{MgSO}_{4}(0.001) \\
\text { EDTA }(0.01) ; \mathrm{MgSO}_{4}(0.02)\end{array}$ & $\begin{array}{l}73 \\
71 \\
60 \\
89 \\
89 \\
82\end{array}$ & $\begin{array}{l}37 \\
\mathbf{5 0} \\
\mathbf{5 5} \\
\mathbf{2 9} \\
\mathbf{2 9} \\
\mathbf{3 2}\end{array}$ & $\begin{array}{c}56 \\
56 \\
2 \cdot 0 \\
65 \\
48 \\
8\end{array}$ & $\begin{array}{l}21 \\
23 \\
0 \cdot 01 \\
59 \\
45 \\
0 \cdot 8\end{array}$ \\
\hline 2 & 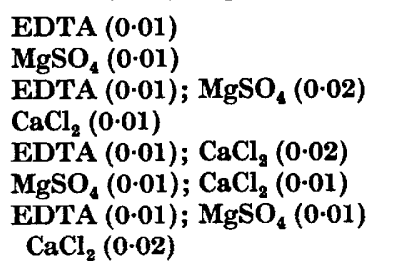 & $\begin{array}{l}\mathbf{3 5} \\
83 \\
80 \\
97 \\
83 \\
98 \\
83\end{array}$ & $\begin{array}{l}81 \\
27 \\
33 \\
24 \\
28 \\
\mathbf{2 2} \\
\mathbf{2 8}\end{array}$ & $\begin{array}{l}1 \cdot 0 \\
48 \\
22 \\
47 \\
28 \\
48 \\
31\end{array}$ & $\begin{array}{l}0 \cdot 2 \\
22 \\
2 \cdot 1 \\
32 \\
22 \\
34 \\
24\end{array}$ \\
\hline
\end{tabular}

* Additions to $0.01 \mathrm{~m}$ tris $\mathrm{HCl}(\mathrm{pH} \mathrm{7.4})$. $†$ Percentage of turbidity of culture. $¥$ Sum of $260 \mathrm{~m} \mu$ extinction of washings as \% of alkali lysate.

these changes was about the same for either buffer. Tris buffer was used for most of the experiments to be described. The effect of $\mathrm{pH}$ value was not investigated. The addition of $\mathrm{MgSO}_{4}$ or $\mathrm{CaCl}_{2}$ in concentrations of $0.01 \mathrm{M}$ or higher decreased these 
changes (Table 1), whereas ethylenediaminetetra-acetic acid (EDTA) at 0.01 M increased them, its effect on the loss of viability being greater after storage (Table 2). At one-tenth this concentration, EDTA had no effect on survival, but increased the leakage of u.v.-absorbing material. $\mathrm{Mg}^{2+}(0.01 \mathrm{~g}$. ions/l. $)$ prevented almost completely the decrease of turbidity, and the loss of u.v.-absorbing material which

Table 3. The effect of polyamines on the stability of Mycoplasma mycoides

$\begin{array}{lcc}\begin{array}{c}\text { Polyamine* } \\ \text { (M concn.) }\end{array} & \begin{array}{c}\text { Turbidity } \\ (\%) \dagger\end{array} & \begin{array}{c}\text { Extinction at } \\ \mathbf{2 6 0} \mathrm{m} \mu(\%) \ddagger\end{array} \\ \text { None } & 71 & \mathbf{2 1 . 4} \\ \text { Spermine (0.00001) } & 80 & 18 \cdot 7 \\ \text { Spermine (0.0001) } & 86 & 13.5 \\ \text { Spermine (0.001) } & 89 & 11 \cdot 7 \\ \text { Spermine (0.005) } & 95 & 11 \cdot 7 \\ \text { Spermidine (0.0001) } & 78 & 17 \cdot 0 \\ \text { Spermidine (0.001) } & 87 & 13 \cdot 4 \\ \text { Spermidine (0.005) } & 97 & 13.3 \\ \text { 1,4-Diaminobutane (0.005) } & 83 & 19.5\end{array}$

* Added to (0.01 M tris $\mathrm{HCl}(\mathrm{pH} 7 \cdot 4)$. † Percentage of turbidity of culture. $¥$ Sum of $260 \mathrm{~m} \mu$ extinction of washings as \% of alkali lysate.

Table 4. The effect of $\mathrm{Mg}^{2+}, \mathrm{Ca}^{2+}$ and spermine on the stability of Mycoplasma mycoides

\begin{tabular}{|c|c|c|c|c|c|c|}
\hline \multirow[b]{2}{*}{ Expt. } & \multirow{2}{*}{$\begin{array}{l}\text { Cation additions } \\
\text { (M concn.) }\end{array}$} & \multirow{2}{*}{$\begin{array}{l}\text { Turbidity } \\
\text { (\%)t }\end{array}$} & \multirow{2}{*}{$\begin{array}{c}\text { Extinction } \\
\text { at } 260 \mathrm{~m} \mu \\
(\%) \ddagger\end{array}$} & \multicolumn{3}{|c|}{$\begin{array}{l}\text { Viable count }(\%) \text { after } \\
\text { stated period at } 0-2^{\circ}\end{array}$} \\
\hline & & & & $2 \mathrm{hr}$ & $24 \mathrm{hr}$ & $48 \mathrm{hr}$ \\
\hline 1 & $\begin{array}{l}\text { None } \\
\mathrm{MgSO}_{\mathbf{4}}(0 \cdot 01) \\
\mathrm{CaCl}_{\mathbf{a}}(0 \cdot 01) \\
\text { Spermine }(0.001)\end{array}$ & $\begin{array}{l}59 \\
79 \\
87 \\
82\end{array}$ & $\begin{array}{l}35 \\
19 \\
17 \\
14\end{array}$ & $\begin{array}{l}21 \\
39 \\
21 \\
20\end{array}$ & $\begin{array}{r}11 \\
43 \\
25 \\
3\end{array}$ & - \\
\hline 2 & $\begin{array}{l}\text { None } \\
\mathrm{MgSO}_{4}(0 \cdot 01) \\
\mathrm{CaCl}_{2}(0 \cdot 01) \\
\text { Spermine }(0 \cdot 001)\end{array}$ & $\begin{array}{l}68 \\
90 \\
92 \\
96\end{array}$ & $\begin{array}{l}32 \\
20 \\
16 \\
15\end{array}$ & $\begin{array}{l}42 \\
75 \\
41 \\
50\end{array}$ & $\begin{array}{l}19 \\
81 \\
47 \\
10\end{array}$ & $\begin{array}{r}11 \\
70 \\
41 \\
4\end{array}$ \\
\hline $\mathbf{3}$ & $\begin{array}{l}\text { None } \\
\text { MgSO }_{4}(0.01) \\
\text { Spermine }(0.001)_{\text {MgSO }_{4}(0.01) \dagger}\end{array}$ & $\begin{array}{r}76 \\
88 \\
95 \\
104\end{array}$ & $\begin{array}{l}30 \\
24 \\
18 \\
17\end{array}$ & $\begin{array}{l}41 \\
60 \\
49 \\
38\end{array}$ & $\begin{array}{l}- \\
-\end{array}$ & $\begin{array}{r}12 \\
28 \\
6 \\
32\end{array}$ \\
\hline
\end{tabular}

* Added to $0.01 \mathrm{~m}$ tris $\mathrm{HCl}(\mathrm{pH} \mathrm{7.4})$. $†$ Percentage of turbidity of culture. $\ddagger$ Sum of $260 \mathrm{~m} \mu$ extinction of washings as $\%$ of alkali lysate.

occurred in the presence of $0.01 \mathrm{~m}$-EDTA alone, but only partly prevented the effect of EDTA (0.01 M) on survival (Table 2$)$. $\mathrm{Ca}^{2+}(0.01 \mathrm{~g}$ ions/l.) almost completely prevented the lethal effect of EDTA $(0.01 \mathrm{M})$ as well as preventing effects on turbidity and on loss of u.v.-absorbing material (Table 2).

Polyamines. Spermine (0.0001 $\mathrm{M}$ ) had about the same effect as $0.01 \mathrm{M}-\mathrm{MgSO}_{4}$ or 0.01 ${\mathrm{M}-\mathrm{CaCl}_{2}}_{2}$ on turbidity and the loss of u.v.-absorbing material. Spermidine $(0.001 \mathrm{M})$ had about the same effect as $0.0001 \mathrm{M}$-spermine; 1,4-diaminobutane had little effect at 0.005 м (Table 3). Spermine, in contrast to $\mathrm{MgSO}_{4}$ and $\mathrm{CaCl}_{2}$, did not 
increase the survival of viable particles during storage, although the organisms survived in its presence when $\mathrm{MgSO}_{4}$ was also added (Table 4). Spermine (0.001 M) was as effective as $\mathrm{Ca}^{2+}(0.01 \mathrm{~g}$. ions/1.) in preventing the effects of $0.01 \mathrm{M}$-EDTA on the loss of u.v.-absorbing material and on turbidity (Table 5).

Table 5. The effect of $\mathrm{Ca}^{2+}, \mathrm{EDT} A$ and spermine on the stability of Mycoplasma mycoides

Tris $=0.01 \mathrm{~m}$-tris $\mathrm{HCl}(\mathrm{pH} \mathrm{7 \cdot 4}) ; \mathrm{P}=0.01 \mathrm{~m}-\mathrm{Na}_{2} \mathrm{HPO}_{4}+\mathrm{KH}_{2} \mathrm{PO}_{4}(\mathrm{pH} \mathrm{7.4}) ; \mathrm{Suc}=0.4 \mathrm{~m}-$ sucrose.

$$
\begin{aligned}
& \multicolumn{1}{c}{\begin{array}{c}
\text { Composition } \\
\text { (M concn.) }
\end{array}} \\
& \text { Tris + } \mathrm{CaCl}_{2}(0 \cdot 01) \\
& \text { Tris + EDTA }(0 \cdot 01) \\
& \text { Tris + EDTA }(0 \cdot 01)+\mathrm{CaCl}_{2}(0 \cdot 02) \\
& \text { Tris + EDTA (0.01) + spermine (0.001) } \\
& \text { P+EDTA }(0 \cdot 01) \\
& \text { P+EDTA (0.01) + spermine (0.001) } \\
& \text { P+Suc + EDTA }(0 \cdot 01) \\
& \text { P + Suc + EDTA (0.01) + spermine (0.001) }
\end{aligned}
$$

Turbidity
$(\%)^{*}$
93
55
80
76
49
75
34
73

Extinction at $260 \mathrm{~m} \mu(\%) \dagger$

20
43
23
23
43
24
51
21

\begin{tabular}{|c|c|c|c|c|}
\hline $\begin{array}{c}\text { Added } \\
\text { solute } \\
\text { (M concn.)* }\end{array}$ & $\begin{array}{l}\text { Total solute } \\
\text { concn. } \\
\text { (molal) }\end{array}$ & Turbidity $\dagger$ & $\begin{array}{l}\text { Extinction } \\
\text { at } 260 \mathrm{~m} \mu \\
(\%) \ddagger\end{array}$ & $\begin{array}{l}\text { Viable count } \\
(\%) \text { after } \\
1 \mathrm{hr} \text { at } 0^{\circ}\end{array}$ \\
\hline None & 0.03 & 78 & 22 & 45 \\
\hline Sucrose $(0.25)$ & $\mathbf{0} \cdot 30$ & 67 & 30 & 32 \\
\hline Sucrose $(0 \cdot 4)$ & 0.50 & 61 & 25 & 36 \\
\hline $\mathrm{NaCl}(0 \cdot 15)$ & $\mathbf{0} \cdot 30$ & 65 & 35 & 42 \\
\hline $\mathrm{NaCl}(0.25)$ & $0 \cdot 50$ & 65 & 35 & 30 \\
\hline $\mathrm{KCl}(0 \cdot 15)$ & 0.30 & 70 & 34 & 58 \\
\hline $\mathrm{KCl}(0 \cdot 25)$ & $0 \cdot 50$ & 61 & 33 & 30 \\
\hline
\end{tabular}

20

43

$\mathbf{2 3}$

43

51

21

* Percentage of turbidity of culture. + Sum of $260 \mathrm{~m} \mu$ extinction of washings as \% of alkali lysate.

Table 6. The effect of sucrose, $\mathrm{NaCl}$ and $\mathrm{KCl}$ on the stability of $\mathrm{Mycoplasma}$ mycoides

* Added to $0.01 \mathrm{M}$-tris $\mathrm{HCl}+0.01 \mathrm{~m}-\mathrm{MgSO}_{4} .+$ Percentage of turbidity of culture. $\ddagger$ Sum of $260 \mathrm{~m} \mu$ extinction of washings as \% of alkali lysate.

Tonicity. In the absence of stabilizing cations, the decrease in turbidity and the loss of u.v.-absorbing material were greater when the organisms were washed and suspended in solutions containing sucrose $(0 \cdot 4 \mathrm{M})$ than they were in hypotonic solutions. In the presence of stabilizing cations the addition of sucrose made little difference. The effects of adding sucrose $(0.25 \mathrm{M}, 0.4 \mathrm{M})$ and of $\mathrm{NaCl}$ and $\mathrm{KCl}$ $(0.15 \mathrm{M}$ and $0.25 \mathrm{M})$ to tris $+\mathrm{MgSO}_{4}(0.01 \mathrm{M})$ solution are shown in Table 6. The decrease in turbidity and the loss of u.v.-absorbing material were slightly greater, and survival about the same, in the presence of these solutes as they were in the suspension in hypotonic solution.

\section{Effects on morphology}

Observations were made by dark field microscopy and by electron microscopy of formaldehyde-fixed or glutaraldehyde-fixed suspensions of Mycoplasma mycoides. The cultures examined contained a high proportion of filamentous organisms, but 
other forms were also present. The filaments were preserved after washing and fixing in solutions having a total solute concentration of $\mathbf{0 . 3}$ or $\mathbf{0 . 5}$ molal (dilutebuffer + sucrose or $\mathrm{NaCl}$ ) followed by washing in water. There were no filaments in suspensions of organisms washed and fixed in hypotonic (0.03 molal) solutions. Electron micrographs of these suspensions showed electron-dense almost spherical forms, flattened forms and other material. The addition of stabilizing cations or of EDTA had no marked effects on the morphology of the organisms when suspended either in sucrose $(0.5 \mathrm{molal})$ or in hypotonic $(0.03$ molal $)$ solutions.

\title{
Table 7. Effect of tonicity of suspending medium on the packed cell volume of Mycoplasma strains $v 5$ and $N$
}

\begin{abstract}
Organisms were washed and suspended in 0.5 molal solution. 1 vol. suspension was added to $10 \mathrm{vol}$. solution of molality 0.03 or 0.5 , and the suspensions were then centrifuged in graduated capillary-tipped tubes at $1850 \mathrm{~g}$ for $18 \mathrm{hr}$ at $2^{\circ}$. The cell volumes recorded are the pellet volumes from which the intercellular volumes (as determined by the amount of PVP in the pellets) were subtracted.
\end{abstract}

\begin{tabular}{cccc} 
Strain & $\begin{array}{c}\text { Age of culture } \\
(\text { hr) }\end{array}$ & $\begin{array}{c}\text { Molal solute } \\
\text { concentration* }\end{array}$ & $\begin{array}{c}\text { Cell vol. } \\
(\mu l .)\end{array}$ \\
v5 & 40 & 0.07 & 41 \\
& & 0.50 & 23 \\
v5 & \multirow{2}{*}{18} & 0.07 & 18 \\
& & 0.50 & 8.5 \\
N & 18 & 0.07 & 9.6 \\
& & 0.50 & 5.4
\end{tabular}

* Composition of solution: $0.01 \mathrm{~m}$-tris $\mathrm{HCl}(\mathrm{pH} 7 \cdot 4)$. + $0.01 \mathrm{M}-\mathrm{MgSO}_{4}+1 \% \mathrm{w} / \mathrm{v}$ polyvinylpyrrolidone $(\mathrm{PVP})+$ sucrose $0.02 \mathrm{M}$ (total solute concentration $=0.07 \mathrm{molal})$, or $\mathbf{0 . 4} \mathrm{M}$ (total solute concentration $=\mathbf{0 . 5 0}$ molal $)$.

The effects of the tonicity of the suspending fluid on morphology, and the reversibility of these changes, are illustrated in Pl. 1, figs. 1-3; figs. $1 a$ and $1 b$ show the organisms after they had been washed and resuspended in $0.01 \mathrm{M}$-phosphate $+0.01 \mathrm{M}$ $\mathrm{MgSO}_{4}+0.001 \mathrm{~m}$-spermine $+0.4 \mathrm{M}$-sucrose solution (hypertonic solution); figs. $2 \mathrm{a}$ and $2 b$ show their appearance after they had been washed in the hypertonic solution and then suspended in a solution of the same composition but lacking sucrose (hypotonic solution); figs. $3 a$ and $3 b$ show their appearance after they had been suspended successively in hypertonic, hypotonic and again hypertonic solutions. The flattened forms seen in Pl. 1, figs. $2 a$ and $2 b$, may have been spherical in suspension and have collapsed during drying on the grids. Dark field examination of the unfixed suspension in a light microscope showed only what appeared to be spherical forms of various diameters with a maximum of about $1 \mu$. The rapidity of the shape changes was evident from the complete absence of streaming birefringence in the suspension in hypotonic solution and its immediate reappearance when the organisms were resuspended in hypertonic solutions. Measurements of cell volumes by using polyvinylpyrrolidone to measure the volume of the intercellular space in the cell pellets are shown in Table 7. Organisms were harvested from an exponential phase culture of Mycoplasma mycoides strain $\mathbf{} 5$ which contained numerous filaments, from a stationary phase culture of $\mathrm{v} 5$ strain which did not contain filaments, and from an exponential phase culture of the $M$. capri strain $\mathrm{N}$ which consisted 
mostly of short rod-like forms. The cell volumes were, in each case, about twice as great when the organisms were suspended in hypotonic solution as when in hypertonic solution.

\section{DISCUSSION}

These observations support those of others (Smith \& Sasaki, 1958; Butler \& Knight, 1960; Razin, 1963) that Mycoplasma organisms survive well in hypotonic solutions. They differ from those reported by Butler \& Knight (1960) who found that, within an optimal concentration range, metal chelating agents, including EDTA, increased survival. In the experiments reported here, EDTA decreased survival and turbidity and increased the loss of u.v.-absorbing material, whereas $\mathrm{Ca}^{2+}$ and $\mathrm{Mg}^{2+}$ had a stabilizing effect. These conflicting results may be due to differences in concentrations of toxic metal ion impurities. The stabilizing effects of divalent cations and of polyamines for Mycoplasma mycoides are similar to those described by Tabor (1962) for bacterial protoplasts and spheroplasts and by Razin (1964) for M. laidlawii. Razin found that any of a series of divalent and trivalent cations as well as spermine and spermidine at $10^{-5} \mathrm{M}$ and even lower concentrations, prevented lysis during incubation of suspensions of $M$. ladlawii at $37^{\circ}$. Spermine at $10^{-5} \mathrm{M}$ also prevented death in a hypotonic medium. In the experiments reported here, spermine did not prevent death of $M$. mycoides. The observed interactions between $\mathrm{Ca}^{2+}, \mathrm{Mg}^{2+}$, spermine and EDTA may be the result of a competition between EDTA and the cell membrane for $\mathrm{Ca}^{2+}$ and $\mathrm{Mg}^{2+}$ on the one hand, and between $\mathrm{Ca}^{2+}, \mathrm{Mg}^{2+}$ and spermine for common binding sites on the membrane on the other.

Mycoplasma mycoides responds to changes in the tonicity of the suspending solution by changes in shape and volume. The volume changes for individual undamaged organisms may be larger than those measured for the whole suspensions, because many of the organisms may have been damaged and their property of responding to osmotic pressure changes destroyed during the manipulations. In the case of the highly filamentous organisms of the $v 5$ strain harvested from the $18 \mathrm{hr}$ culture, the volume changes may have been considerably larger than the measurements shown in Table 7 for another reason. $M$. mycoides synthesizes a large amount of polysaccharide which is believed to form an extracellular capsular or slime layer closely surrounding the organisms in young cultures and later shed into the medium (Plackett et al. 1963). The suspension of organisms harvested from the younger culture would therefore contain a much larger amount of this extracellular material. The ratio of the volume to the number of turbidity units in the samples centrifuged was about four-fold greater for the suspension from the $18 \mathrm{hr}$ culture than it was for the suspension from the $\mathbf{4 0} \mathrm{hr}$ culture. The filaments have a very large ratio of surface area to volume. If a filament $0.1 \mu$ in diameter and $7 \mu$ in length and bounded by a membrane $85 \AA$ in thickness were transformed to a sphere of the same surface area, the volumes within the external and internal surfaces of the membrane would increase by factors of 5.5 and 8 , respectively; the diameter of the sphere would be $0 \cdot 8 \mu$. This is about the diameter of the larger forms observed by dark field examination in a light microscope in unfixed suspensions in hypotonic solution. The plastic filamentous mycoplasmas therefore have the potential to increase their volume several-fold by dilution of their contents (that is to decrease their-inernal ostmotic pressure) without an increase in surface area. This may help to explain their 
relative tolerance to osmotic pressure changes compared with bacterial protoplasts, whose volume, within a narrower tonicity range, is inversely related to the osmotic pressure of the medium (Weibull, 1955) but which undergo lysis in dilute solutions. Razin (1963) found that the sensitivity of certain Mycoplasma strains to osmotic lysis decreased with the age of the culture. The older cultures would contain few filaments. Changes in size, shape, lipid composition of membrane, and internal osmotic pressure are doubtless important also in determining stability. All of these may change with age of culture.

I am indebted to Mr A. Abbot of the Walter and Eliza Hall Institute of Medical Research for the electron micrographs.

\section{REFERENCES}

Butler, M. \& KNight, B. C. J. G. (1960). The survival of washed suspensions of mycoplasma. J. gen. Microbiol. 22, 470.

Plackett, P., Buttery, S. H. \& Cottew, G. S. (1963). Carbohydrates of some Mycoplasma strains. Recent Progress in Microbiology: Symp. 8 int. Congr. Microbiol. p. 535.

RAzIN, S. (1963). Osmotic lysis of Mycoplasma. J. gen. Microbiol. 33, 471.

Razin, S. (1964). Factors influencing osmotic fragility of Mycoplasma. J. gen. Microbiol. 36, 451 .

Razin, S. \& Argaman, M. (1963). Lysis of Mycoplasma, bacterial protoplasts and L-forms by various agents. J. gen. Microbiol. 30, 155.

Smith, P. F. \& SASAKI, S. (1958). Stability of pleuropneumonia-like organisms to some physical factors. Appl. Microbiol. 6, 184.

TABOR, C. W. (1962). Stabilization of protoplasts and spheroplasts by spermine and other polyamines. J. Bact. 83, 1101.

Weibull, C. (1955). Osmotic properties of protoplasts of Bacillus megatherium. Exp. Cell. Res. 9, 294.

Wetherell, D. F. \& Pollack, J. D. (1962). Polyvinylpyrrolidone as an indicator for measuring intercellular space in packed cell pellets. J. Bact. 84, 191.

\section{EXPLANATION OF PLATE}

Figs. 1-3 illustrate the effect of the tonicity of the suspending medium on the shape of Mycoplasma mycoides organisms. Figs. $1 a, b$ are of organisms washed and suspended in a solution of $0.01 \mathrm{~m}$ phosphate (pH 7.4) + 0.01 M-MgSO +0.001 M-spermine + 0.4 M-sucrose (hypertonic solution). Figs. $2 a, b$ are of organisms washed in hypertonic solution and then suspended in a solution of the same composition but lacking sucrose (hypotonic solution). Figs. $\mathbf{3} a, b$ are of organisms suspended successively in hypertonic, hypotonic and then hypertonic solutions. The organisms for figs. 1-3 were then fixed for $18 \mathrm{hr}$ at $0^{\circ}$ in solutions of the same composition but containing $5 \%$ (w/v) glutaraldehyde, and washed and suspended in water. Gold-palladium shadowed. Figs. $1 a, 2 a$ and $3 a, \times 1500$; figs. $1 b, 2 b$ and $3 b, \times 8600$. 

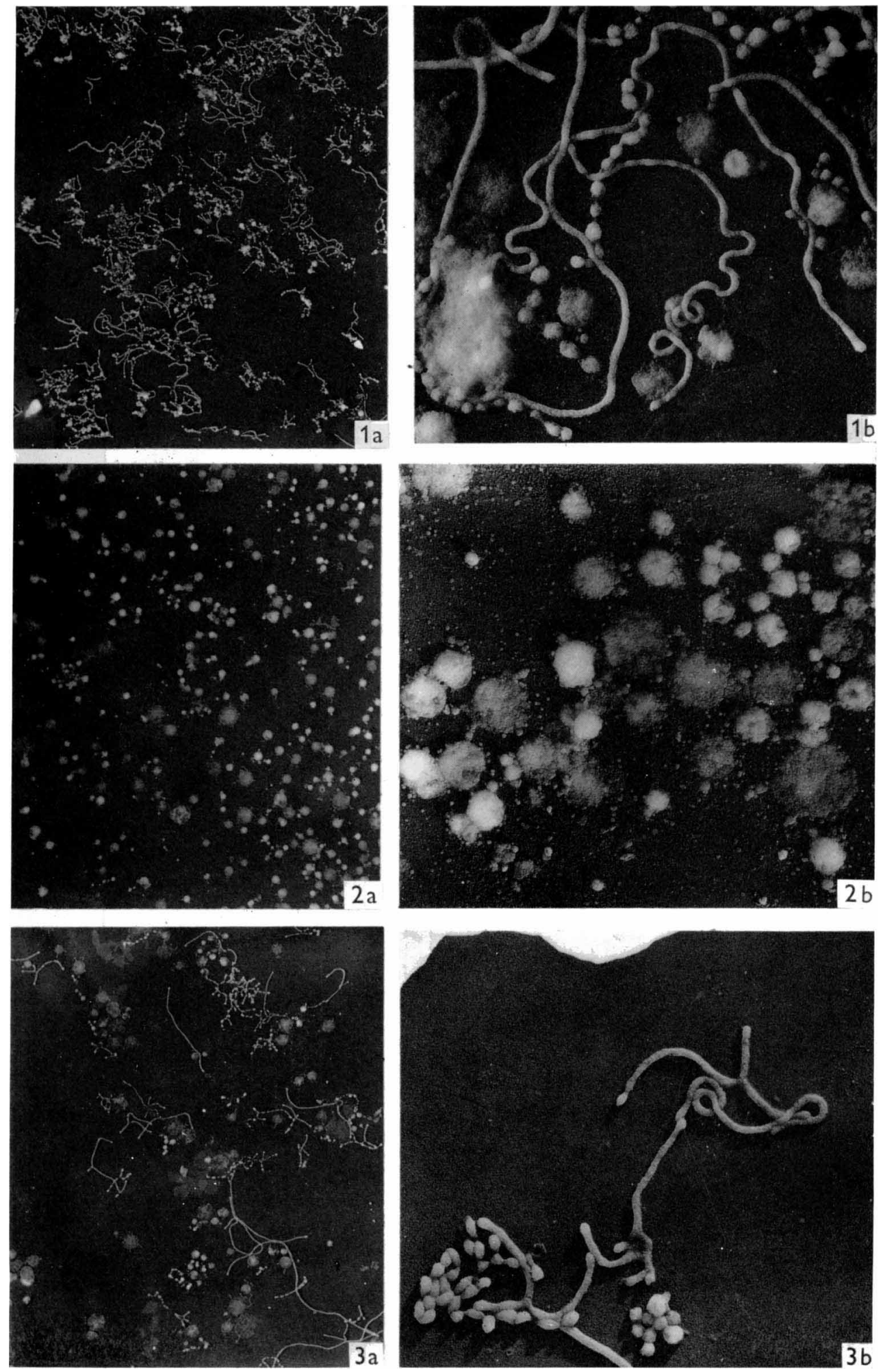